\title{
The Inward-Outward Dichotomy in Robert Bly's Poetry: A Postmodern Psychoanalytic Approach
}

\author{
By \\ Ibrahim Farghal Ahmed Farghal \\ Demonstrator, Department of English, Faculty of Arts
}

\begin{abstract}
2018
Abstract

This paper attempts to uncover the inward and the outward dichotomy in Robert Bly's poetry in terms of postmodernism and psychoanalysis. It
\end{abstract}

The significance of Bly's poetry lies in the fact that that he embodies the psychospiritual problems and suggests solutions to overcome these complex problems. In this paper, he highlights the conflict between the inner world and the outer world in some selected poems and tackles the solution at the end of his second volume the Light around the Body. Bly adopts many concepts and ideas from Jungian psychology to convey his message. There are many postmodern features in Bly's poetry, including inwardness, iconoclasm, fragmentation, intertextuality and formlessness.

Keywords: Robert Bly - the inner world - the outer world - Carl Jung contemporary American poetry - Jacob Boehme - postmodernism psychoanalysis.

The inner world is a main concern for postmodern poetry. Unlike modernist poets who were mainly concerned with the outer world, postmodern poets are masters of the inner world and they seek to achieve a balance and harmony between the two worlds so as to live a balanced life between spirituality and materiality. Bly adopts this dichotomy from the outstanding mystical thinker in the 17th century, Jacob Boehme. Robert Bly is one of the prominent poets in contemporary American poetry. Bly attempts to embody and reflect the gap and the conflict between the two worlds then he offers some solutions to achieve the harmonized soul between the two worlds.

Robert Bly is one of the most outstanding and influential contemporary American poets. Donald Hall praises Robert Bly as "the most systematic poet in the United States" (89). He began his literary career at the beginning of the 
sixties with the publication of his volume Silence in the Snowy Fields (1962) which was described as a rebellious book by Howard Nelson. As a postmodern poet, Bly is an incisive critic of modernist poetry, for there are stark oppositions between Bly's thought and that of his modernist forebears. In his critical essay "A Wrong Turning in American Poetry", Bly attacks postmodern poets such as Eliot, Pound and Williams, for modernist poetry depends only the outer world and ignores the inner world. Bly's significance lies not only in being a poet and critic but also in his influence on a whole generation of American poets through his literary magazine - the Fifties: A Magazine of Poetry and General Opinion.

In her Critical essay, "The Successful Career of Robert Bly", Dana Gioia describes Robert Bly as "one of the most famous and influential poets now writing in America"(207). As a postmodern poet, Bly is greatly influenced by romanticism. In his anthology News of the Universe, Bly confirms that "contemporary nature poetry grows out of the romantic tradition" (Quetchenbach 3). According to William Heyen, Bly is "a romantic. Yeats was not the last, for all our inner men are" (17). The difference between Bly and other English Romantics is that he uses modern psychology to explore the inner world and achieve a harmony between the inner world and the outer world. For example, Jungian psychology has helped Bly to be one of the great masters of the inner life in contemporary American literature. Thus, we can compare Bly to other great psychological masters such as Pablo Neruda in Spain, Goethe in Germany, and Tomas Transromer in Sweden.

\section{The separation between the inner and outer world}

In a poem entitled "A man writes to a part of himself", Bly he highlights the gap between the two worlds. This poem is one of the most significant, interesting poems in Silence in the Snowy Fields, for it embodies the separation and the gap between the inner world and the outer one by a separation between a wife and a husband. The wife embodies the inner world and the husband embodies the outer world. The poet says:

"What cave are you in, hiding, rained on?

Like a wife, starving, without care,

Water dripping from your head, bent

Over ground corn ...

You raise your face into the rain

That drives over the valley

Forgive me, your husband,

On the streets of a distant city, laughing,

With many appointments,

Though at night going also

To a bare room, a room of poverty, 
To sleep among a bare pitcher and basin

In a room with no heat

Which of us two then is the worse off?

And how did this separation come about?" (1-15)

From a postmodern approach, intertextuality is a postmodern feature in this poem. Bly's reliance on the Boehmean dichotomy of inwardness and outwardness is indicative. He uses the following excerpt from Jacob Boehme as an epigraph to his volume, Silence in the Snowy Fields and the Light around the Body:

For according to the outward man, we are in this world, and according to the inward world, we are in the inward world... since then we are generated out of both worlds, we speak in two languages, and we must be understood also by two languages. (Light 1)

In the above excerpt, man cannot live alone in the outer world and ignores the inner world, which comes at first place for a balanced psychological life. The transformation from inwardness into outwardness and vice versa is called Leaping poetry. Bly personifies his anima as a wife who has been left alone without care and starving as described in the poem, "a wife, starving, without care"(2). The ego is embodied as a husband who enjoys his life with many appointments in the daylight, but in the night he suffers from loneliness and grief described as "a room of poverty/... a room with no heat "(11-13). When a unity happens between the anima and the ego, the anima will be a source of life and nourishment.

A second fundamental postmodern aspect in this poem is iconoclasm. Throughout his poetry, Bly concentrates on decanonizing and decentering the western standard of male consciousness, which neglects the feminine principles of the human psyche. Bly calls all human beings, through the collective unconscious, to take the inner path and warns them against neglecting the feminine features to achieve his/her psychic wholeness. Moreover, he explores the reason for the separation as embodied in the lines "Which of us two then is the worse off?/ And how did this separation come about?"(14-15). Thus, Bly attempts to explore the reasons for the gap between the two worlds so as to be able to solve and overcome the conflict.

From a psychoanalytic perspective, Bly directs the attention of his readers feminine consciousness, for "if this life of the unconscious remains ignored, this dreamer may have increasingly intense "struggles" during the nightworse and worse "horrors" to be suppressed" (Harris 71). The feminine is "the emotional, the mysterious, the inspirational; the masculine is the rational, the realistic, the intellectual. The best poetry is achieved by a wedding of the two characteristics (Green 3). Bly mingles the feminine and the 
masculine aspects in his poetry, for they are significant for a balanced psychological life. Carlanda Green defines the feminine principle as follows:

The female principle derives from the Earth Mother herself and from man's pull toward the land and toward woman. It is a principle establishing certain basic qualities associated with the female, whether human or animal, animate or inanimate. The feminine essence may be embodied in a woman, an otter, a cow, or a water pump. Wherever it is found, the feminine principle indicates an otherness about the female, an instinctive difference in the way she perceives life and reacts to it. Her actions are often intuitive; she senses, feels things to a greater degree than man so that the felt experience is a commonplace with her. Because he often cannot understand how she knows what she knows, man, chiefly rational, finds her mysterious and often mistrusts her. Without her, however, he is fragmented and disoriented. (5-6)

The female principle is completely different from the male one in its perception of life. Such principle cannot be understood through the rational parts of the human psyche but only through intuition. Without the female principle, man is fragmented and lost. In the final line in the poem Bly examines the reasons for the separation between the ego and the anima. A communication must happen between any man and anima or a woman and her animus.

\section{The conflict between the inner world and the outer world}

Bly refers to this conflict between the inner world and the outer world in some poems. In his volume the Light around the Body (1967), Bly identifies and explores the relation between the inner /spiritual world and the outer/political world in order to create a balance between these two contradictory realms. In "come with me", Bly compares the inner world and the outer world. The poet says:

"Come with me into those things that have felt his despair for so long-

Those removed Chevrolet wheels that howl with a terrible loneliness,

Lying on their backs in the cindery dirt, like men drunk, and naked,

Staggering off down a hill at night to drown at last in the pond.

Those shredded inner tubes abandoned on the shoulders of thruways,

Black and collapsed bodies, that tried and burst, 
And were left behind;

And the curly steel shavings, scattered about on garage

benches,

Sometimes still warm, gritty when we hold them,

Who have given up, and blame everything on the government,

And those roads in South Dakota that feel around

in the darkness ..." (1-17)

From a postmodern perspective, inwardness is a postmodern determinant in this poem. Bly identifies the conflict between the inner world and the outer world, and there is a transformation from one world to another. He calls this transformation leaping poetry. The poet compares the inner spiritual life of men with abandoned car parts. These men suffer from many inner spiritual problems as described in the poem "howl with a terrible loneliness"(3-4). The inner lives of the men are imaged as "Those shredded inner tubes"(9). He describes men as "drunk, and naked, /staggering off down a hill at night to drown at last in the pond" (6-7). Thus, there are many forms of conflict between the two worlds in this poem.

Another main concern of postmodernism in this poem is fragmentation. The poem incorporates and fuses two contradicting, opposing worlds: the inner world and the outer world. Furthermore, the poet uses images from these worlds which result in a kind of fragmentation in the poem. For instance, the poet refers to the outer world as "those removed Chevrolet wheels that howl with a terrible loneliness"(3-4), and refers to the inner world as "those shredded inner tubes abandoned on the shoulders of thruways"(9-10). Each world has its own nature, language and symbology.

From a psychoanalytic perspective, the poet is an archetypal hero who is taking the journey into the American inward life. According to Mary Ruby, the poet acts as "a guide, imploring the reader to follow him into the depths of things containing secret knowledge about human existence. He shows the reader how inanimate objects can evoke feelings of grief by describing them as if they had human properties" (29). The poem is an inner reflection of the corruption and fraud of the outer, political world and its impact on the inner world.

Another poem that highlights the conflict between the inner world and outer world is "Romans Angry about the Inner World". Bly says:

"What shall the world do with its children?

At sixteen we have experiences

And we float

Joyfully on the dark places. 


\author{
But the executioners \\ Move toward Drusia. \\ They tie her legs \\ On the iron horse: "Here is a woman \\ Who has caught a glimpse of Our Mother \\ In the other world!" Next they warm \\ The hooks. The Romans had put their trust \\ In iron. Irons glowed \\ Like teeth. They asked her \\ To assure them. She refused. Finally \\ They took burning \\ Pine sticks, and pushed them \\ Into her side. Her breath rose \\ And she died. (1-21)
}

From a postmodern perspective, intertextuality is a postmodern feature in this poem. Bly's reliance on the Boehmean dichotomy of the inner world and the outer world. The poem incorporates and fuses these two contradicting, opposing worlds: the inner world and the outer world. The inner world is symbolized by a woman" a woman/ who has seen our mother/ in the other world!."(11-12) and the outer world is symbolized by the Romans" the Romans had put their trust in iron"(14-15). At the very beginning of the poem, the poet describes the childhood stage and the primacy of the inner world at that stage, for children are born with a knowledge of the joy of the inner world.

Another main concern of postmodernism in this poem is inwardness. Children have the pleasure and the joy of the inner world. They could have many wonderful experiences at the age of sixteen as described in the poem " At sixteen we have experiences/ and we float joyfully on the dark places"(26). Leaping of the body they live only in the inner world before they get acquainted with the outer world. The old men know nothing about the joy of the inner world. The first line of the poem highlights the enduring power of the inner world against the outer world. He refers to the inner world in the first line as "what shall the world do with its children?"(1). For Bly, every child is "born with a knowledge of the joy of the inner world, how can the social forces of the outer world ever obliterate the inner world without obliterating themselves" (Sugg 53).

A third postmodern feature in this poem is formlessness. The poet merges the past and the present in highlighting the inner and the outer worlds in terms of the masculine and the feminine aspects of the human psyche so as to show the enemies of the inner worlds. The suffering of the woman is imaged as" a woman/ who has seen our mother/ in the other world!." According to Paul 
Lacey, the representatives of the outer world in this poem are Romans. Furthermore, "they are not ignorant of the inner world; they are its enemies" (124). Thus, the American politicians and the Romans are the enemies of the inner world in the past and the present. But the difference here is that Bly wants America to change and take care of the inner life of people or it will collapse like Rome.

From a psychoanalytic perspective, the mother is an archetypal symbol of the Great mother in its positive aspects. According to Wilfred Guerin, the archetypal woman is the great mother, and refers to the mysteries of life, death, transformation. Furthermore, it is associated with the life principle, birth, warmth, nourishment, protection, fertility, growth and abundance (228). The woman is the representative of the inner, spiritual world, and the prosecutors are representatives of the outer, political world. They killed the woman because she belongs to another world different from their own.

It is significant to identify the relation between America and ancient Rome. In his essay "I came out of the mother Naked", Bly argues that the mother suppressed by one culture can return in another, thus the woman, that was tortured by Rome, return again in America as imaged in the poem "the inner world is a thorn/ in the ear of a tiny beast!/ it is a jagged stone/ Flying toward us out of the darkness". According to Robert Bly, "America is still young... and she may become something magnificent and shinning, or she may turn, as Rome did, into a black dinosaur, the enemy of every nation in the world who wants to live its own life. In my opinion, that decision has not been made "(Morning 105). Bly advises The American people to stop being the enemy of the inner world and achieves a harmony between the inner world and the outer one so as to live a balanced psychic life.

\section{The harmonized soul between the two worlds}

The final section in the Light around the Body is titled "A Body Not Yet Born". This section is characterized by a hopeful poetry of transformation from the outward world into the inward life and achieving the harmonized soul. The first poem that highlights the returning to the inner world is "Looking into a face". The poet says:

"Conversation brings us so close! Opening

The surfs of the body,

Bringing fish up near the sun,

And stiffening the backbones of the sea!

I have wandered in a face, for hours,

Passing through dark fires.

I have risen to a body 
Not yet born,

Existing like a light around the body,

Through which the body moves like a sliding moon". (1-10)

From a postmodern perspective, a postmodern aspect in this poem is iconoclasm. The poet decanonizes and resists the American reliance and trust in the outer, material world and their hatred and ignorance of the inner, spiritual world. The poem describes the outward man moving inward as described in the poem "Conversation brings us so close! Opening the surfs of the body/ Bringing fish up near the sun, and stiffening the backbones of the sea!"(1-4). Furthermore, the poet seeks to solve the conflict between the spiritual world and the political world through achieving a harmony between these contradictory worlds. In other words, the poet seeks to achieve a "world of the inner spirit"(Sugg 68).

Another postmodern concern in this poem is inwardness. The outward man via a series of leaps the open the surfs of body moves inward at last in order to achieve "a body not yet born"(7-8) as described in the poem " I have risen to a body, not yet born/ Existing like a light around the body, through which the body moves like a sliding moon"(7-10).

Another poem that tackles the primacy and the significance of the inner world for perfecting the outer world is "When the Dumb speak". It is the last poem in the volume titled the Light around the Body (1967). This poem is fundamental and significant for understanding Bly's political poetry. The poem unifies the two major themes of the volume: the inner world and the corruption of the outward world. Bly says:

There is a joyful night in which we lose

Everything, and drift

Like a radish

Rising and falling, and the ocean

At last throws us into the ocean,

Then the images appear:

Images of death,

Images of the body shaken in the grave,

And the grave filled with seawater;

Fires in the sea,

The ships smoldering like bodies,

Images of wasted life,

Life lost, imagination ruined,

The house fallen,

The gold sticks broken, 
Then shall the talkative be silent,

And the dumb shall speak. (1-24)

From a postmodern perspective, inwardness is a postmodern feature in this poem. The poet describes the transformation from the outer world in to the inner world in the poem as "there is a joyful night in which we lose/ everything, and drift Like a radish/ Rising and falling, and the ocean At last throws us into the ocean"(1-5). The inner world is a world of beauty, joy and peace.

A second postmodern aspect in this poem is intertextuality. The title of the poem refers to a biblical allusion of the prophecy of Isaiah. This prophecy is about" the miracles that will accompany the triumphant second coming of the savior, and " the dumb shall sing" in a verse known to many through its inclusion in Handel's Messiah" (Sugg 68). Has this allusion to do something with the title of the poem? Yes, there is a close link between the allusion and the title of the poem. Following the transformation from the inner world into the outer world, a lot of images of apocalypse appear such as "Images of death, Images of the body shaken in the grave / Images of wasted life, Life lost, imagination ruined, the house fallen"(14-22). These wicked events happen in preparation for "a new order, ruled by the laws of the harmonized soul achieved through the pursuit of inwardness (Sugg 68).

A third postmodern concern in this poem is iconoclasm. The poet decanonizes and resists the American reliance and trust in the outer, political world and their hatred and ignorance of the inner, spiritual world. Furthermore, the poet seeks to ease the conflict between the spiritual world and the political world through achieving a harmony between these contradictory worlds. In other words, the poet seeks to achieve a "world of the inner spirit" (Sugg 68). Following the achievement of the inner life, man can live a balanced, integrated and spiritual life.

\section{Conclusion}

This paper has attempted to uncover the inward-outward dichotomy in Bly's poetry in terms of postmodernism and psychoanalysis. Bly is one of the prominent poets in contemporary American poets. Unlike modernist poets, the inner world is a main concern for postmodern poets, and Bly is no exception. Throughout his poetry, Bly has attempted to portray the gap and the conflict between the inner world and the outer world. Then, he suggests some solutions to achieve a harmony and balance between these contradictory worlds. he is a poet of the inner world. His poetry affirms the primacy and significance of the inner world so as to live a balanced life between spirituality and materialism. 
The most powerful and memorable poems are "A man writes to a part of himself" and "Romans angry about the inner world", for there are representatives from the two worlds in each poem which helped to embody and clarify the conflict between the two worlds. The poet employs many postmodern features such as inwardness, intertextuality, fragmentation, formlessness and iconoclasm which helped to convey his themes and views. There are also some psychoanalytic features in the selected poems, including the inner world, the feminine principle, the mother archetype and the archetypal hero. Such postmodern and psychanalytic features play a vital role in the treatment of the inner and outer worlds.

Bly yearns for a harmony and balance between these contradictory realms. In his poem" A man writes to a part of himself", he identifies the separation between the two worlds in terms of a separation between a wife and a husband. In "Romans angry about the inner world" and "come with me", he explores the conflict between the two worlds. In "Looking into a face" and "When the Dumb speak", Bly seeks to achieve a "world of the inner spirit" to as to be unity, integration and balance between the two worlds. Bly concentrates on decanonizing and decentering the dominance of the outer world and the marginalization of the inner world. Through the collective unconscious, Bly calls to a return to the feminine aspects of the human psyche. As a neoromantic poet, Bly is interested in the inner life of man and the feminine consciousness. Bly longs for a reunion between the masculine and the feminine aspects, which results in happy, balanced life.

\section{Works Cited}

Bly, Robert. "A Wrong Turning in American Poetry." Claims for Poetry (1982): 17-37. Print.

---. "I Came out of the Mother Naked." Sleepers Joining Hands (1973). Print.

---. Silence in the Snowy Fields; Poems. 1st ed. Middletown, Conn.,: Wesleyan 
University Press, 1962. Print.

---. Talking All Morning. University of Michigan Press, 1980. Print.

---. The Light around the Body; Poems. 1st ed. New York,: Harper \& Row, 1967. Print.

Davis, William Virgil. Understanding Robert Bly. Understanding Contemporary American Literature. Columbia, S.C.: University of South Carolina Press, 1988. Print.

Gioia, Dana. "The Successful Career of Robert Bly." The Hudson Review 40.2 (1987): 207-23. Print.

Green, Carlanda. "The Feminine Principle in Seamus Heaney's Poetry." ARIEL: A Review of International English Literature 14.3 (1983). Print.

Guerin, Wilfred L. A Handbook of Critical Approaches to Literature. Oxford University Press, USA, 2005. Print.

Hall, Donald. "Notes on Robert Bly and Sleepers Joining Hands." Ohio Review 15, no 918 (1973):89-93.

Harris, Victoria Frenkel. The Incorporative Consciousness of Robert Bly: Victoria Frenkel Harris. SIU Press, 1992. Print.

Heyen, William. "Inward to the World: The Poetry of Robert Bly." The Far Point 3 (1969): 42-50. Print.

Napierkowski, Mafia Rose, and Mary K Ruby. "Poetry for Students, Vol. 2." Detroit: The Gale Group, 1998. Print.

Quetchenbach, Bernard W. Back from the Far Field: American Nature Poetry in the Late Twentieth Century. University of Virginia Press, 2000. Print.

Sugg, Richard P. Robert Bly. Twayne's United States Authors Series. Boston, Mass.: Twayne Publishers, 1986. Print. 